\title{
СВОЄЧАСНІСТЬ ДОСТАВКИ ХВОРИХ ІЗ ТРАВМАМИ ВНУТРІШНІХ ОРГАНІВ ГРУДНОЇ ТА ЧЕРЕВНОЇ ПОРОЖНИНИ І ТАЗА ТА ГОСТРИМИ ЗАХВОРЮВАННЯМИ ОРГАНІВ ЧЕРЕВНОЇ ПОРОЖНИНИ У ЛІКАРНЯНІ ЗАКЛАДИ ЯК ПРОБЛЕМА ПЕРВИННОЇ МЕДИКО-САНІТАРНОЇ дОПОМОГИ
}

\author{
ДУ «Український інститут стратегічних досліджень Міністерства охорони здоров'я України»,
} м. Київ, Україна

Мета: вивчити та проаналізувати рівні доставки хворих з травмами внутрішніх органів грудної та черевної порожнини і таза та гострими захворюваннями органів черевної порожнини пізніше 24 годин у лікарняні заклади системи охорони здоров'я в аспекті проблем первинної медико-санітарної допомоги.

Матеріали і методи. Матеріалами дослідження стали дані галузевої статистичної звітності за 2010-2014 рр. щодо рівнів звернення хворих у лікарняні заклади системи охорони здоров'я України. Основним методом дослідження був статистичний метод.

Результати. Встановлені високі показники звернення хворих з травмами внутрішніх органів грудної та черевної порожнини і таза та гострими захворюваннями органів черевної порожнини за медичною допомогою в терміни пізніше 24 годин після травми (початку захворювання). Дані показники мають достовірні відмінності за регіонами.

Висновки. Високі показники несвоєчасного звернення за медичною допомогою хворих із травмами внутрішніх органів грудної та черевної порожнини і таза та гострими захворюваннями органів черевної порожнини вказують на низьку ефективність диспансеризації хворих та недостатній рівень санітарно-просвітницької роботи сімейних лікарів.

КЛЮЧОВІ СЛОВА: травма внутрішніх органів грудної та черевної порожнини і таза, гострі захворювання органів черевної порожнини, термін звернення по медичну допомогу, несвоєчасність.

Якість та ефективність медичної допомоги значно залежать від своєчасності звернення пацієнтів так званого «терапевтичного вікна» [1;3;7]. Для пацієнтів із травмами внутрішніх органів грудної та черевної порожнини і таза та гострими захворюваннями органів черевної порожнини «терапевтичним вікном» $€ 24$ години з моменту отримання травми чи початку гострого захворювання [2;6]. Важливу роль у питаннях своєчасного звернення хворих за медичною допомогою відіграє первинна медико-санітарна допомога, яка наразі активно реформується в Україні [4;5].

Мета роботи: вивчити та проаналізувати рівні доставки хворих на травми внутрішніх органів грудної та черевної порожнини і таза та гострі захворювання органів черевної порожнини пізніше 24 годин 3 моменту отримання травми чи початку гострого захворювання у лікарняні заклади системи охорони здоров'я України в аспекті проблем первинної медико-санітарної допомоги.

Матеріали і методи. Основним методом дослідження став статистичний метод. Матеріалами дослідження стали результати галузевої статистичної звітності за 2010-2014 рр. щодо рівнів

(с О.М. Дзюба, Ю.В. Бурдим, В.Г. Слабкий, 2016 доставки хворих на травми внутрішніх органів грудної та черевної порожнини і таза та гострі захворювання органів черевної порожнини пізніше 24 годин з моменту отримання травми чи початку гострого захворювання в лікарняні заклади системи охорони здоров'я України.

Результати дослідження та їх обговорення. На початку дослідження були вивчені та проаналізовані дані щодо рівня доставки хворих на травми внутрішніх органів грудної та черевної порожнини та таза пізніше 24 годин 3 моменту отримання травми чи початку гострого захворювання в лікарняні заклади системи охорони здоров'я України. Як видно з таблиці 1, за роки дослідження вказані показники знизилися на 0,8\% і в 2014 р. склали 17,3\%. При цьому зареєстровані достовірні відмінності показника в розрізі регіонів України. Граничні показники відрізняються в 27,4 разу - від 1,1\% у Луганській до $30,1 \%$ в Одеській області. За роки дослідження даний показник знизився в 13 (52,0\%) та збільшився в $12(48,0 \%)$ регіонах.

Наступним етапом дослідження було вивчення рівнів доставки хворих з окремими станами у лікувальні заклади пізніше 24 годин з моменту початку гострого захворювання. 
Таблиця 1. Рівні доставки хворих на травми внутрішніх органів грудної та черевної порожнини і таза пізніше 24 годин у лікарняні заклади системи охорони здоров'я України, 2010-2014 рр., \%

\begin{tabular}{|l|c|c|c|c|c|c|}
\hline \multicolumn{1}{|c|}{ Адміністративний регіон } & 2010 & 2011 & 2012 & 2013 & 2014 & 2014 до 2010 \\
\hline Вінницька & 22,5 & 22,8 & 28,7 & 27,7 & 29,8 & $+7,3$ \\
\hline Волинська & 11,9 & 10,4 & 13,5 & 15,7 & 10,0 & $-1,9$ \\
\hline Дніпропетровська & 17,7 & 15,5 & 15,5 & 11,8 & 16,1 & $-1,6$ \\
\hline Донецька & 23,1 & 23,5 & 24,0 & 23,1 & 9,4 & $-13,7$ \\
\hline Житомирська & 13,9 & 15,8 & 14,7 & 16,5 & 15,6 & $+1,7$ \\
\hline Закарпатська & 11,6 & 7,5 & 6,3 & 4,5 & 1,3 & $-10,3$ \\
\hline Запорізька & 21,9 & 21,9 & 23,8 & 19,7 & 25,0 & $+3,1$ \\
\hline Івано-Франківська & 2,6 & 4,1 & 3,5 & 3,8 & 7,1 & $+4,5$ \\
\hline Київська & 12,7 & 7,6 & 9,4 & 11,4 & 9,1 & $-3,6$ \\
\hline Кіровоградська & 14,5 & 17,2 & 18,1 & 17,4 & 17,8 & $+3,3$ \\
\hline Луганська & 15,7 & 14,0 & 8,6 & 9,3 & 1,1 & $-14,6$ \\
\hline Львівська & 23,6 & 22,8 & 23,9 & 24,8 & 27,3 & $+3,7$ \\
\hline Миколаївська & 31,5 & 24,0 & 30,5 & 21,7 & 27,6 & $-3,9$ \\
\hline Одеська & 22,9 & 22,2 & 18,5 & 21,8 & 30,1 & $+7,2$ \\
\hline Полтавська & 22,6 & 21,8 & 19,9 & 21,5 & 24,5 & $+1,9$ \\
\hline Рівненська & 9,1 & 8,5 & 5,4 & 7,3 & 3,1 & $-6,0$ \\
\hline Сумська & 19,0 & 18,7 & 18,1 & 21,0 & 10,6 & $-8,4$ \\
\hline Тернопільська & 6,7 & 9,3 & 7,8 & 14,0 & 11,3 & $+4,6$ \\
\hline Харківська & 20,3 & 20,2 & 21,7 & 26,0 & 19,1 & $-1,2$ \\
\hline Херсонська & 25,4 & 29,2 & 22,3 & 18,9 & 18,2 & $-7,2$ \\
\hline Хмельницька & 15,6 & 11,6 & 10,6 & 8,6 & 9,5 & $-6,1$ \\
\hline Черкаська & 15,6 & 19,0 & 22,8 & 21,9 & 26,2 & $+10,6$ \\
\hline Чернівецька & 13,0 & 11,8 & 27,2 & 13,5 & 17,6 & $+4,6$ \\
\hline Чернігівська & 23,4 & 23,7 & 22,4 & 26,6 & 21,8 & $-1,6$ \\
\hline м. Київ & 13,6 & 11,1 & 11,8 & 12,1 & 15,1 & $+1,5$ \\
\hline Україна & $\mathbf{1 8 , 1}$ & $\mathbf{1 7 , 3}$ & $\mathbf{1 7 , 6}$ & $\mathbf{1 6 , 9}$ & $\mathbf{1 7 , 3}$ & $\mathbf{- 0 , 8}$ \\
\hline
\end{tabular}

Вивчення рівнів доставки хворих на гострий панкреатит пізніше 24 годин у лікарняні заклади системи охорони здоров'я показало, що за роки дослідження вказаний показник знизився на 2,0\% і в 2014 р. склав 37,9\%. Аналіз наведених у таблиці 2 даних вказує на достовірні відмінності показника за регіонами. Граничні рівні показника за регіонами становлять від 12,9\% у Сумській до 50,6\% у Харківській області. Різниця становить 3,9 разу. За роки дослідження даний показник знизився в $16(64,0 \%)$ та збільшився в $9(36,0 \%)$ регіонах.

Далі вивчався та аналізувався показник рівня доставки хворих на гострий холецистит пізніше 24 годин у лікарняні заклади системи охорони здоров'я України. Наведені в табл. 3 дані вказують на те, що за роки дослідження цей показник знизився на $3,2 \%$ і в 2014 р. становив 44,9\%. Виявлено достовірні відмінності показника за регіонами. Граничні рівні показника за регіонами становлять від 10,1\% у Закарпатській до 64,2\% у Житомирській області. Різниця становить 6,4 разу. За роки дослідження даний показник знизився в 13 (52,0\%) та збільшився в 11 (44,0\%), без змін залишився в одному $(4,0 \%)$ регіоні.

Також було вивчено та проаналізовано рівні доставки хворих на проривну виразку шлунка та 12-палої кишки пізніше 24 годин у лікарняні заклади системи охорони здоров'я України (табл. 4). За роки дослідження цей показник збільшився на $2,3 \%$ і в 2014 р. становив 17,5\%. Аналіз наведених у таблиці даних вказує на достовірні відмінності показника за регіонами. Граничні рівні показника за регіонами становлять від 2,6\% у Тернопільській до $25,8 \%$ у Херсонській області за відсутності таких пацієнтів у Луганській області. За роки дослідження даний показник знизився у 7 (32,0\%) та підвищився у $16(64,0 \%)$ регіонах, залишився без змін у Київській області.

Далі було вивчено та проаналізовано рівні доставки хворих на шлунково-кишкову кровотечу пізніше 24 годин у лікарняні заклади системи охорони здоров'я України. За роки дослідження цей показник при шлунково-кишкових кровотечах зменшився на 1,5\% і в 2014 р. склав 35,2\%. Аналіз наведених у таблиці 5 даних вказує на достовірні відмінності показника за регіонами. Граничні рівні показника за регіонами становлять від 17,4\% у Луганській до 48,8\% у Херсонській області. Гранична різниця становить 2,8 разу. За роки дослідження даний показник знизився в $15(60,0 \%)$ та збільшився в $10(40,0 \%)$ регіонах. 
Таблиця 2. Рівні доставки хворих на гострий панкреатит пізніше 24 годин у лікарняні заклади системи охорони здоров'я України, 2010-2014 рр., \%

\begin{tabular}{|l|c|c|c|c|c|c|}
\hline \multicolumn{1}{|c|}{ Адміністративний регіон } & 2010 & 2011 & 2012 & 2013 & 2014 & 2014 до 2010 \\
\hline Вінницька & 43,9 & 31,9 & 37,6 & 36,8 & 42,0 & $-1,9$ \\
\hline Волинська & 40,1 & 32,0 & 36,9 & 38,6 & 40,8 & $+0,7$ \\
\hline Дніпропетровська & 36,6 & 37,5 & 33,7 & 33,6 & 35,0 & $-1,6$ \\
\hline Донецька & 50,3 & 47,5 & 48,7 & 48,5 & 39,5 & $-10,8$ \\
\hline Житомирська & 42,2 & 37,1 & 41,9 & 45,1 & 42,1 & $-0,1$ \\
\hline Закарпатська & 16,4 & 19,5 & 13,6 & 14,4 & 13,8 & $-2,6$ \\
\hline Запорізька & 34,4 & 34,7 & 35,3 & 36,6 & 35,5 & $+1,1$ \\
\hline Івано-Франківська & 17,3 & 17,3 & 15,4 & 17,0 & 20,7 & $+3,4$ \\
\hline Київська & 29,8 & 33,2 & 34,7 & 34,5 & 31,9 & $+2,1$ \\
\hline Кіровоградська & 30,1 & 30,1 & 32,8 & 36,9 & 34,5 & $+4,4$ \\
\hline Луганська & 32,5 & 25,4 & 21,7 & 19,6 & 16,1 & $-16,4$ \\
\hline Львівська & 39,0 & 40,6 & 38,2 & 35,4 & 36,9 & $-2,1$ \\
\hline Миколаївська & 43,8 & 41,5 & 43,5 & 41,6 & 42,1 & $-1,7$ \\
\hline Одеська & 46,6 & 39,9 & 42,2 & 45,0 & 39,5 & $-7,1$ \\
\hline Полтавська & 40,1 & 38,8 & 37,5 & 44,8 & 39,1 & $-1,0$ \\
\hline Рівненська & 22,8 & 21,2 & 25,3 & 22,3 & 22,6 & $-0,2$ \\
\hline Сумська & 19,3 & 20,2 & 15,0 & 14,7 & 12,9 & $-6,4$ \\
\hline Тернопільська & 31,9 & 25,1 & 28,4 & 37,3 & 28,6 & $-3,3$ \\
\hline Харківська & 46,8 & 47,6 & 47,3 & 46,8 & 50,6 & $+3,8$ \\
\hline Херсонська & 53,0 & 46,5 & 47,3 & 49,8 & 45,9 & $-7,1$ \\
\hline Хмельницька & 24,7 & 36,7 & 38,7 & 37,5 & 36,7 & $+12,0$ \\
\hline Черкаська & 46,5 & 40,7 & 44,5 & 39,7 & 48,0 & $+1,5$ \\
\hline Чернівецька & 47,0 & 38,3 & 44,3 & 34,5 & 31,0 & $-16,0$ \\
\hline Чернігівська & 46,2 & 41,3 & 37,7 & 44,1 & 44,0 & $-2,2$ \\
\hline м. Київ & 44,3 & 44,2 & 46,3 & 42,8 & 43,8 & $-0,5$ \\
\hline Україна & 39,9 & 38,5 & 38,8 & 38,7 & 37,9 & $-2,0$ \\
\hline
\end{tabular}

Таблиця 3. Рівні доставки хворих на гострий холецистит пізніше 24 годин у лікарняні заклади системи охорони здоров'я України, 2010-2014 рр., \%

\begin{tabular}{|l|c|c|c|c|c|c|}
\hline \multicolumn{1}{|c|}{ Адміністративний регіон } & 2010 & 2011 & 2012 & 2013 & 2014 & 2014 до 2010 \\
\hline Вінницька & 54,1 & 53,9 & 54,8 & 56,3 & 59,8 & $+5,7$ \\
\hline Волинська & 36,5 & 35,6 & 36,9 & 35,0 & 33,0 & $-3,5$ \\
\hline Дніпропетровська & 44,7 & 46,3 & 44,0 & 41,4 & 47,0 & $+2,3$ \\
\hline Донецька & 46,8 & 49,9 & 51,2 & 53,2 & 45,0 & $-1,8$ \\
\hline Житомирська & 49,9 & 49,2 & 55,8 & 59,2 & 64,2 & $+14,3$ \\
\hline Закарпатська & 23,1 & 22,7 & 13,8 & 12,9 & 10,1 & $-13,0$ \\
\hline Запорізька & 37,1 & 37,7 & 37,8 & 38,4 & 37,1 & $=$ \\
\hline Івано-Франківська & 20,6 & 20,0 & 22,7 & 24,1 & 24,9 & $+4,3$ \\
\hline Київська & 35,8 & 40,3 & 41,4 & 39,5 & 41,8 & 6,0 \\
\hline Кіровоградська & 48,8 & 41,5 & 40,4 & 36,9 & 37,5 & $-11,3$ \\
\hline Луганська & 29,2 & 27,3 & 28,0 & 20,8 & 22,4 & $-6,8$ \\
\hline Львівська & 56,5 & 57,1 & 52,8 & 51,4 & 52,9 & $-3,6$ \\
\hline Миколаївська & 49,9 & 52,4 & 51,8 & 44,8 & 48,3 & $-1,6$ \\
\hline Одеська & 55,2 & 48,3 & 44,3 & 43,4 & 37,1 & $-18,1$ \\
\hline Полтавська & 51,0 & 50,8 & 52,4 & 55,9 & 53,1 & $+2,1$ \\
\hline Рівненська & 26,6 & 29,3 & 29,7 & 32,4 & 26,9 & $+0,3$ \\
\hline Сумська & 28,7 & 31,6 & 20,6 & 17,9 & 18,6 & $-10,1$ \\
\hline Тернопільська & 30,1 & 28,7 & 33,9 & 29,0 & 25,4 & $-4,7$ \\
\hline Харківська & 55,5 & 54,4 & 59,6 & 56,8 & 57,0 & $+1,5$ \\
\hline Херсонська & 65,3 & 66,4 & 59,6 & 61,8 & 60,9 & $-4,4$ \\
\hline Хмельницька & 28,2 & 36,6 & 43,5 & 42,4 & 39,3 & $+11,1$ \\
\hline Черкаська & 45,5 & 61,8 & 60,5 & 58,6 & 61,3 & $+15,8$ \\
\hline Чернівецька & 60,9 & 49,7 & 46,2 & 42,4 & 29,4 & $-31,5$ \\
\hline Чернігівська & 58,1 & 54,2 & 45,0 & 47,0 & 50,4 & $-7,7$ \\
\hline м. Київ & 47,7 & 55,9 & 57,2 & 49,9 & 53,7 & $+6,0$ \\
\hline Україна & 48,1 & 47,6 & 47,3 & 46,0 & 44,9 & $-3,2$ \\
\hline
\end{tabular}


Таблиця 4. Рівні доставки хворих на проривну виразку шлунка та 12-палої кишки пізніше 24 годин у лікарняні заклади системи охорони здоров'я України, 2010-2014рр., \%

\begin{tabular}{|l|c|c|c|c|c|c|}
\hline Адміністративний регіон & 2010 & 2011 & 2012 & 2013 & 2014 & 2014 до 2010 \\
\hline Вінницька & 19,3 & 22,1 & 19,8 & 20,2 & 25,7 & $+6,4$ \\
\hline Волинська & 10,4 & 8,7 & 10,2 & 10,3 & 11,6 & $+1,2$ \\
\hline Дніпропетровська & 16,3 & 18,0 & 16,9 & 21,6 & 17,5 & $+1,2$ \\
\hline Донецька & 21,6 & 20,5 & 23,9 & 25,6 & 23,1 & $+1,5$ \\
\hline Житомирська & 14,9 & 11,9 & 17,4 & 17,0 & 19,0 & $+4,1$ \\
\hline Закарпатська & 9,0 & 9,6 & 12,3 & 5,8 & 7,5 & $-1,5$ \\
\hline Запорізька & 19,1 & 20,7 & 20,2 & 14,4 & 22,5 & $+3,4$ \\
\hline Івано-Франківська & 3,8 & 10,3 & 4,9 & 12,1 & 13,3 & $+9,5$ \\
\hline Київська & 10,3 & 8,6 & 10,9 & 11,7 & 10,3 & + \\
\hline Кіровоградська & 14,8 & 15,3 & 13,4 & 11,8 & 14,7 & $-0,1$ \\
\hline Луганська & 3,7 & 6,0 & 4,7 & 3,9 & - & $-3,7$ \\
\hline Львівська & 15,1 & 18,4 & 21,7 & 20,3 & 20,2 & $+5,1$ \\
\hline Миколаївська & 13,6 & 16,3 & 15,8 & 12,7 & 15,5 & $+1,9$ \\
\hline Одеська & 16,2 & 18,4 & 17,9 & 18,3 & 22,8 & $+6,6$ \\
\hline Полтавська & 13,1 & 15,3 & 17,2 & 15,4 & 17,1 & $+4,0$ \\
\hline Рівненська & 4,4 & 7,2 & 4,8 & 7,4 & 11,2 & $+6,8$ \\
\hline Сумська & 8,6 & 9,2 & 5,4 & 7,7 & 6,4 & $-2,2$ \\
\hline Тернопільська & 3,1 & 5,3 & 3,1 & 5,1 & 2,6 & $-0,5$ \\
\hline Харківська & 18,2 & 24,9 & 25,9 & 24,6 & 23,7 & $+5,5$ \\
\hline Херсонська & 22,7 & 24,8 & 21,1 & 23,1 & 25,8 & $+3,1$ \\
\hline Хмельницька & 15,7 & 12,0 & 13,0 & 16,4 & 12,2 & $-3,5$ \\
\hline Черкаська & 14,1 & 13,2 & 13,5 & 17,9 & 19,7 & $+5,6$ \\
\hline Чернівецька & 13,0 & 11,5 & 22,1 & 7,5 & 5,1 & $-7,9$ \\
\hline Чернігівська & 17,1 & 18,0 & 22,7 & 21,9 & 14,9 & $-2,2$ \\
\hline м.Київ & 21,6 & 30,8 & 26,2 & 22,9 & 23,4 & $+1,8$ \\
\hline Україна & 15,2 & 17,0 & 17,2 & 17,2 & 17,5 & $+2,3$ \\
\hline
\end{tabular}

Таблиця 5. Рівні доставки хворих на шлунково-кишкову кровотечу пізніше 24 годин у лікарняні заклади системи охорони здоров'я України, 2010-2014 рр., \%

\begin{tabular}{|l|c|c|c|c|c|c|}
\hline Адміністративний регіон & 2010 & 2011 & 2012 & 2013 & 2014 & 2014 до 2010 \\
\hline Вінницька & 33,6 & 35,6 & 25,0 & 31,7 & 44,0 & $+10,4$ \\
\hline Волинська & 33,3 & 35,8 & 33,5 & 32,2 & 33,4 & $+0,1$ \\
\hline Дніпропетровська & 40,8 & 43,3 & 36,9 & 39,3 & 30,0 & $-10,8$ \\
\hline Донецька & 41,0 & 40,4 & 37,4 & 34,4 & 47,1 & $+6,1$ \\
\hline Житомирська & 30,2 & 28,1 & 31,3 & 31,5 & 38,2 & $+8,0$ \\
\hline Закарпатська & 17,1 & 17,0 & 18,3 & 15,7 & 19,4 & $+2,3$ \\
\hline Запорізька & 46,9 & 41,5 & 37,9 & 37,9 & 37,9 & $-9,0$ \\
\hline Івано-Франківська & 19,7 & 14,2 & 22,5 & 18,7 & 18,8 & $-0,9$ \\
\hline Київська & 21,9 & 19,2 & 27,5 & 25,0 & 20,8 & $-1,1$ \\
\hline Кіровоградська & 30,5 & 36,5 & 29,8 & 32,1 & 30,0 & $-0,5$ \\
\hline Луганська & 22,5 & 20,5 & 27,5 & 21,9 & 17,4 & $-5,1$ \\
\hline Львівська & 36,5 & 35,5 & 35,2 & 32,0 & 34,5 & $-2,0$ \\
\hline Миколаївська & 39,0 & 42,2 & 32,3 & 39,6 & 33,8 & $-5,2$ \\
\hline Одеська & 46,0 & 47,4 & 44,6 & 44,3 & 39,0 & $-7,0$ \\
\hline Полтавська & 42,8 & 40,9 & 43,7 & 43,4 & 46,9 & $+4,1$ \\
\hline Рівненська & 23,4 & 20,0 & 24,4 & 21,2 & 21,9 & $-1,5$ \\
\hline Сумська & 16,3 & 18,0 & 18,6 & 19,7 & 17,9 & $+1,6$ \\
\hline Тернопільська & 27,8 & 19,0 & 19,9 & 16,8 & 21,0 & $-6,8$ \\
\hline Харківська & 41,3 & 43,1 & 46,5 & 49,9 & 47,2 & $+5,9$ \\
\hline Херсонська & 53,1 & 49,7 & 50,9 & 50,1 & 48,8 & $-4,3$ \\
\hline Хмельницька & 26,9 & 31,1 & 32,9 & 27,1 & 28,5 & $+1,6$ \\
\hline Черкаська & 33,7 & 30,5 & 34,0 & 37,2 & 34,7 & $+1,0$ \\
\hline Чернівецька & 43,4 & 36,8 & 43,0 & 38,1 & 31,7 & $-11,7$ \\
\hline Чернігівська & 47,3 & 44,8 & 47,0 & 40,0 & 44,8 & $-2,5$ \\
\hline м. Київ & 46,3 & 41,8 & 43,1 & 45,1 & 40,8 & $-5,5$ \\
\hline Україна & 36,7 & 36,0 & 35,5 & 34,9 & 35,2 & $-1,5$ \\
\hline
\end{tabular}




\section{Висновки}

3 точки зору оцінки діяльності первинної медико-санітарної допомоги високі показники несвоєчасного звернення за медичною допомогою хворих 3 травмами внутрішніх органів грудної та черевної порожнини і таза та гострими захворюваннями органів черевної порожнини вказують на низьку ефективність диспансеризації хворих та низький рівень санітарно-просвітницької роботи сімейних лікарів.

Перспективи подальших досліджень пов'язані з вивченням ефективності та якості медичної допомоги пацієнтам при травмах внутрішніх органів грудної та черевної порожнини і таза та гострих захворюваннях органів черевної порожнини.

\section{Список літератури}

1. Медико-демографрічна ситуація та основні показники медичної допомоги населенню в регіональному аспекті. 2013 рік. - Київ : МОЗ України, ДУ «УІСД МОЗ України», 2014. - 168 с.

2. Острый панкреатит и его осложнения. - Киев : Наукова думка, 1990. - 271 с.

3. Показники здоров'я населення та використання ресурсів охорони здоров'я в Україні за 2013-2014 роки. - Київ : ЦМС МОЗ України, 2015. - 328 с.

4. Реформування галузі охорони здоров'я: Вінницька, Донецька, Дніпропетровська, Одеська, Полтавська області, м. Київ. Результати, проблеми, шляхи вирішення. - Київ, 2014. - 207 с.

5. Слабкий Г. О. Пріоритетний розвиток первинної медико-санітарної допомоги на засадах сімейної медицини / Г. О. Слабкий, І. С. Зозуля, А. І. Зозуля // Сімейна медицина. 2014. - № 3 (53). - С. 25-27.

6. Шалимов А. А. Хирургия пищеварительного тракта / А. А. Шалимов, В. Ф. Саенко - Киев : Здоров'я, 1987. - 567 с. 7. Щорічна доповідь про стан здоров'я населення, санітарно-епідемічну ситуацію та результати діяльності системи охорони здоров'я України. 2013 рік. - Київ, 2014. - 438 с.

\section{СВОЕВРЕМЕННОСТЬ ДОСТАВКИ БОЛЬНЫХ С ТРАВМАМИ ВНУТРЕННИХ ОРГАНОВ ГРУДНОЙ И БРЮШНОЙ ПОЛОСТИ И ТАЗА И ОСТРЫМИ ЗАБОЛЕВАНИЯМИ ОРГАНОВ БРЮШНОЙ ПОЛОСТИ В БОЛЬНИЧНЫЕ УЧРЕЖДЕНИЯ КАК ПРОБЛЕМА ПЕРВИЧНОЙ МЕДИКО-САНИТАРНОЙ ПОМОЩИ} А.Н. Дзюба, Ю.В. Бурдым, В.Г. Слабкий

ГУ «Украинский институт стратегических исследований Министерства здравоохранения Украины», г. Киев, Украина

Цель: изучить и проанализировать уровни доставки больных с травмами внутренних органов грудной и брюшной полости и таза и острыми заболеваниями органов брюшной полости позже 24 часов в лечебные учреждения системы здравоохранения в аспекте проблем первичной медико-санитарной помощи.

Материалы и методы. Материалами исследования стали данные отраслевой статистической отчетности за 2010-2014 гг. относительно уровней обращения больных в лечебные учреждения системы здравоохранения Украины. Основным методом исследования был статистический метод.

Результаты. Установлены высокие показатели обращаемости больных с травмами внутренних органов грудной и брюшной полости и таза и острыми заболеваниями органов брюшной полости за медицинской помощью в сроки позднее 24 часов после травмы (начала заболевания). Данные показатели имеют достоверные отличия по регионам.

Выводы. Высокие показатели несвоевременного обращения за медицинской помощью больных с травмами внутренних органов грудной и брюшной полости и таза и острыми заболеваниями органов брюшной полости указывают на низкую эффеективность диспансеризации больных и недостаточный уровень санитарно-просветительской работы семейных врачей.

КЛЮЧЕВЫЕ СЛОВА: травма внутренних органов грудной и брюшной полости и таза, острые заболевания органов брюшной полости, срок обращения за медицинской помощью, несвоевременность.

\section{TIMELY DELIVERY OF PATIENTS WITH INJURIES OF INTERNAL ORGANS OF THE CHEST AND ABDOMEN AND PELVIS AND ACUTE DISEASES OF THE ABDOMINAL CAVITY IN HOSPITAL FACILITIES AS A PROBLEM OF PRIMARY CARE}

O.M. Dziuba, Yu.V. Burdym, V.G. Slabkiy

PE "Ukrainian Institute of Strategic Researches MHC of Ukraine", Kyiv, Ukraine Researches MHC

Purpose - to examine and analyze the level of delivery of patients with injuries of internal organs of the chest and abdomen and pelvis and acute diseases of the abdominal cavity after 24 hours in hospital institutions of health problems in the aspect of primary care problems.

Materials and methods. Materials of study were statistical reports for 2010-2014 on equal treatment of patients in hospital facilities of the health system in Ukraine. The main method of study was a statistical method.

Results. The high performance treatment of patients with injuries of internal organs of the chest and abdomen and pelvis and acute diseases of the abdominal cavity for medical care in terms of more than 24 hours after injury (onset) established. These figures are significant differences by region. 
Conclusions. High rates of delayed seeking medical help patients with injuries of internal organs of the chest and abdomen and pelvis and acute diseases of the abdominal cavity indicate low efficiency of clinical examination of patients and insufficient health education of family physicians.

KEY WORDS: internal injuries of the chest and abdomen and pelvis, acute diseases of the abdominal cavity, the term appeal for help, untimely.

Рукопис надійшов до редакції 10.10.2016 p.

\section{Відомості про авторів:}

Дзюба Олександр Миколайович - д.мед.н., проф., заступник директора з наукової роботи дУ „Український інститут стратегічних досліджень Міністерства охорони здоров'я України"; тел. служб.: +38(044) 576-41-49. Бурдим Юрій Володимирович - пошукувач інституту ДУ «Український інститут стратегічних досліджень Міністерства охорони здоров'я України»; тел. служб.: +38(044) 576-41-19.

Слабкий Василь Геннадійович - науковий співробітник інституту ДУ «Український інститут стратегічних досліджень Міністерства охорони здоров'я України»; тел. служб.: +38(044) 576-41-19. 